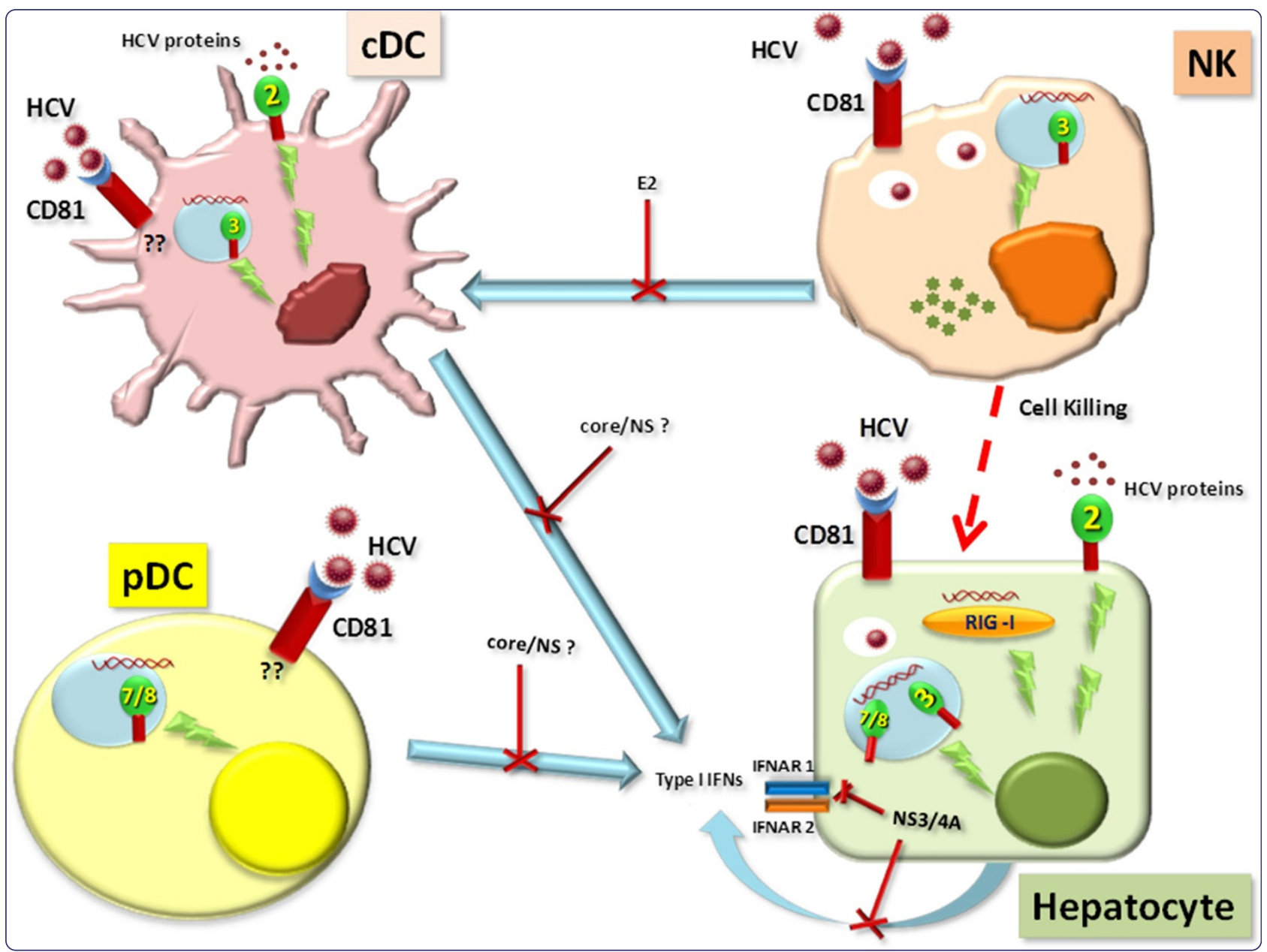

\title{
Innate immunity and hepatitis $C$ virus infection: a microarray's view
}

Buonaguro et al. 


\title{
Innate immunity and hepatitis C virus infection: a microarray's view
}

\author{
Luigi Buonaguro, Annacarmen Petrizzo, Maria Lina Tornesello and Franco M Buonaguro*
}

\begin{abstract}
Hepatitis $\mathrm{C}$ virus (HCV) induces a chronic infection in more than two-thirds of HCV infected subjects. The inefficient innate and adaptive immune responses have been shown to play a major pathogenetic role in the development and persistence of HCV chronic infection. Several aspects of the interactions between the virus and the host immune system have been clarified and, in particular, mechanisms have been identified which underlie the ability of HCV to seize and subvert innate as well as adaptive immune responses. The present review summarizes recent findings on the interaction between HCV infection and innate immune response whose final effect is the downstream inefficient development of antigen-specific adaptive immunity, thereby contributing to virus persistence.
\end{abstract}

Keywords: HCV, Innate immunity, Pattern recognition receptors (PRRs), Interferon stimulated genes (ISGs), Systems biology

\section{Hepatitis C virus: a brief overview}

Hepatitis $\mathrm{C}$ virus (HCV) is a Hepacivirus of the Flaviviridae family, mainly involved in hepatic disorders, including chronic hepatitis which may progress to cirrhosis in about $10-20 \%$ of cases and further to hepatocellular carcinoma (HCC) in $1-5 \%$ of cirrhotic patients [1]. Furthermore, $\mathrm{HCV}$ has also been implicated as one of the major etiologic factors for type II Mixed Cryoglobulinemia (MC), an autoimmune disease that may evolve into an overt B-cell non-Hodgkin's lymphoma (NHL) in about $10 \%$ of $\mathrm{MC}$ patients [2-4].

$\mathrm{HCV}$ is an enveloped positive-strand RNA virus. Six major HCV genotypes and more than 100 subtypes have been so far identified [5-7]. HCV genomic RNA contains a single open reading frame flanked by $5^{\prime}$ and $3^{\prime}$ untranslated regions (UTRs) [8,9], which encodes for a single large polyprotein, processed by cellular and viral proteases to produce structural as well as non structural proteins $[9,10]$.

The core $(\mathrm{C})$ and envelope proteins (E1 and E2) are structural components of the infectious particle [11], whereas the non structural (NS) proteins are required for RNA replication (NS3-NS5B), particle assembly

\footnotetext{
* Correspondence: irccsvir@unina.it

Molecular Biology and Viral Oncogenesis Unit, Istituto Nazionale Tumori "Fond. G. Pascale", 80131, Naples, Italy
}

\section{() Biomed Central}

(p7 and NS2) and protein maturation (NS2 and NS3/4A complex) $[10,12]$.

$\mathrm{HCV}$ entry into hepatocytes is mediated by one of the following putative receptors, such as the CD81 tetraspanin [13], the scavenger receptor class B type I [14], the tight junction proteins claudin [15,16] and occludin [17], the latters conferring species specificity.

\section{Innate immune response to $\mathrm{HCV}$}

As for all microbial infections, innate immune response plays a critical role in the control and resolution of $\mathrm{HCV}$ infection providing signals for the efficient priming of the adaptive branch of immune response $[18,19]$.

In particular, the innate immunity is important in $\mathrm{HCV}$ infection to control viral dissemination and replication in order to allow an adequate downstream development of antigen-specific humoral as well as cellular responses [20].

During the early phase of $\mathrm{HCV}$ infection, the viral RNA load increases in the first few days and remains high throughout the incubation period, which lasts for up to $10-12$ weeks post-infection $[21,22]$. In such early stage, large amounts of type I interferons (IFN- $\alpha$, IFN- $\beta$ ) may be produced by HCV-infected hepatocytes as well as dendritic cells (DCs) to control viral replication [23]. 
Besides producing type I IFN, DCs represent the key cell compartment of innate immunity, orchestrating the quality and potency of downstream adaptive immune response. They are professional antigen presenting cells (APCs) able to uptake and process viral antigens, as well as release cytokines to efficiently prime both CD4+ helper T cells and CD8+ cytotoxic T lymphocytes (CTLs) [24].

In particular, the subset of plasmacytoid DCs (pDCs) is considered the front line in antiviral immunity owing to their capacity to rapidly produce high amounts of type I interferon in response to viruses, upon recognition of viral components and nucleic acids through Toll-like receptor (TLR) 7 and TLR9 [25,26]. To further support such role, several reports show a decreased frequency of pDCs in peripheral blood of patients with chronic HCV infection and impaired production of IFN- $\alpha$ by pDCs from $\mathrm{HCV}$ patients [27-29]. Also, myeloid or conventional DCs (cDCs) are programmed to produce IFN- $\alpha$ in response to viral infection upon interaction between viral doublestranded RNA-like molecule polyinosinic:polycytidylic acid (poly I:C) and TLR3 [30]. Moreover, cDCs produce high amounts of cytokines, such as IL-12, which has been shown to play an important role in stimulating IFN- $\gamma$ production from activated $\mathrm{T}$ cells, inducing the development of type 1 (Th1) protective immune response [31,32]. Indeed, a recent study showed that an increased number of cDCs during acute HCV infection may be associated with viral clearance, whereas a loss in the number of cDCs may increase the risk for development of chronic $\mathrm{HCV}$ infection $[33,34]$.

Also natural killer (NK) cells are potent antiviral effectors due to their contribution to virus elimination via direct killing of infected cells and cytokine production [35]. Genetic factors appear to contribute to the level of NK cell responsiveness, as shown by the presence of individual killer cell Ig-like receptor/human leukocyte antigen (KIR/HLA) compound genotypes correlated with $\mathrm{HCV}$ clearance [36]. In particular, given that the interaction between KIRs expressed on NK cells and HLA expressed on target cells plays a key role in NK cell activation, it has been suggested that such genotypes are characterized by a higher sensitivity of NK cells with a faster degranulation and IFN- $\gamma$ release in vitro [37].

Nevertheless, innate immune response to $\mathrm{HCV}$ may also be detrimental inducing immunopathological effects on the liver. NK-mediated killing of HCV-infected hepatocytes and secretion of proinflammatory cytokines may cause liver damage, stimulating $\mathrm{cDCs}$ to produce high amount of IFN- $\gamma$ which, subsequently, activates hepatic macrophages to enhance local inflammation [38]. All such cascade of events contributes to the pathogenesis of liver disease [39].

The overall data demonstrate the complex, contradictory and evolving equilibrium between $\mathrm{HCV}$ and host innate immunity, whose result will lead to completely different clinical outcomes ranging from resolution to chronic viral infection.

\section{Pattern recognition receptors in sensing virus infection}

The innate immune response to virus infection is activated when conserved motifs of microbial origin, known as pathogen-associated molecular patterns (PAMPs) are recognized by cell pattern recognition receptors (PRRs) [40].

The 3 major classes of PRRs include Toll-like receptors (TLRs), RIG-I-like receptors (RLRs), and nucleotide oligomerization domain (NOD)-like receptors (NLRs) [41-43]. Viral engagement of TLRs and RLRs leads to the activation of transcription factors, such as the IFN regulatory factors (IRFs) and NF- $\mathrm{kB}$, which in turn may lead to the activation of IRF3 target genes, type I IFN, and proinflammatory cytokines [44].

So far, the role of NLRs in sensing RNA viruses is still unclear and they are primarily thought to be activated by intracellular stress signals (i.e. damage-associated molecular patterns, DAMPs) [45]. In this regards, DAMPS derived from $\mathrm{HCV}$ infected hepatocytes may play a critical role in promoting liver inflammation with immunopathological effects.

Innate immune cells (i.e. monocytes, neutrophils, dendritic cells) are rapidly activated upon recognition of infecting agents by a wide range of PRRs. Among them, the Toll-like receptors are members of the interleukin-1 receptor (IL-1R) superfamily [46,47], characterized by a leucine-rich repeat (LRR) domain in the extracellular region and an extracellular Toll/IL-1R (TIR) domain [48].

So far, 11 TLRs have been identified. TLR1, TLR2, TLR6 and TLR10 are closely related to the TLR2 subfamily, whereas, TLR7, TLR8 and TLR9 are closely related to the TLR9 subfamily [49]. Each TLR has specific ligands, which allow the host to sense a wide diversity of pathogens [50]. As a result of TLR stimulation, proinflammatory cytokines are released that activate the host immune response [51-53].

Most TLRs (except for TLR3) share a common signalling pathway, via the adaptor molecule, myeloid differentiation primary response protein 88 (MyD88) [54-56]. TLRs recruit MyD88 via TIR domains, then MyD88 binds the IL-1R-associated kinase (IRAK) and the signal is propagated to tumor necrosis factor (TNF) receptor-associated factor-6 (TRAF6), for activation of NF-kB and mitogenactivated protein kinases (MAPK). A second pathway involves the TIR-associated protein (TIRAP)/MyD88adaptor-like (Mal) for TLR1/2, TLR2/6 and TLR4 signalling $[57,58]$.

On the contrary, TLR3 signalling is independent of MyD88 and is mediated by TIR-domain containing adaptor inducing IFN-b (TRIF)_toll-like receptor adaptor 
molecule I (TICAM I) with induction of interferonregulatory factor-3 (IRF-3) transcription factor and subsequent production of IFN- $\beta$ [59].

The RIG-I-like receptors (RLRs) are sensors of viral RNA, consisting of three members: RIG-I, melanoma differentiation antigen 5 (MDA5) [60] and laboratory of genetics and physiology-2 (LGP2) [61-64]. RLRs are expressed in the cytoplasm of most cells, including hepatocytes, representing good candidates as primary intracellular sensors of $\mathrm{HCV}$ infection. Both RIG-I and MDA5 contain 2 $\mathrm{N}$-terminal caspase activation and recruitment domains (CARD) [65]. Moreover, all the RLRs have a DExD/H RNA helicase domain and bind to RNA ligands [66]. In addition, RIG-I has a repressor domain that interacts with the CARD domains to maintain the receptor in a non-active conformation in the absence of infection [67]. LGP2 lacks the CARD domains and may function as a regulator of RLR signalling [68]. RIG-I senses non-self double-stranded RNAs (dsRNAs) with free $5^{\prime}$-triphosphates and is recruited to the mitochondrial surface, where interacts with MAVS (mitochondrial antiviral signalling protein; also known as IFN- $\beta$ promoter simulator 1 (IPS-1), virus-induced signaling adapter (VISA), and CARD adaptor inducing IFN- $\beta$ (Cardif)) on the outer mitochondrial membrane. MAVS is a CARD protein and an essential adaptor for RLR signalling [69]. The interaction between RIG-I and MAVS results in the activation of the transcription factors, interferon regulatory factor-3 (IRF-3) and nuclear factor-kB (NF-kB) with subsequent transcription of IFN- $\beta$ [70].
Overall, the data show that, regardless the class of PRRs engaged upon viral recognition, the activated pathways in cells of the innate immunity converge to induce the production of type I IFN with highly effective antiviral activity.

\section{IFN signalling during HCV infection}

The production of IFN- $\beta$ resulting from $\mathrm{HCV}$ infection leads to activation of the JAK (Janus kinase)/STAT (signal transducer and activator of transcription) signalling pathway with the expression of interferon-stimulated genes (ISGs) (Figure 1) [71,72].

Among others, an increased expression has been described for the $2^{\prime}-5^{\prime}$-oligoadenylate synthase 1 (OAS1)/ RNAse L system, which degrades viral and cellular RNA [73], and the RNA-specific adenosine deaminase acting on RNA 1 (ADAR1), which converts adenosine residues into inosine residues in dsRNA [74], thereby mutating and destabilizing secondary viral RNA structures [75]. Similarly, induction of other ISGs, such as P56 [76] and protein kinase R (PKR) [77], which inhibit translation of viral and host RNAs [78], has been reported. Such induction of ISGs will ultimately amplify the IFN response, in a loop fashion, given that some pattern recognition and signalling molecules are ISGs per se, such as RIG-I, TLR3 and TRIF, whose final outcome is the production of IFN- $\beta$ (Figure 1) [79].

In this complex framework, HCV establishes a chronic persisting infection when is able to disrupt the host

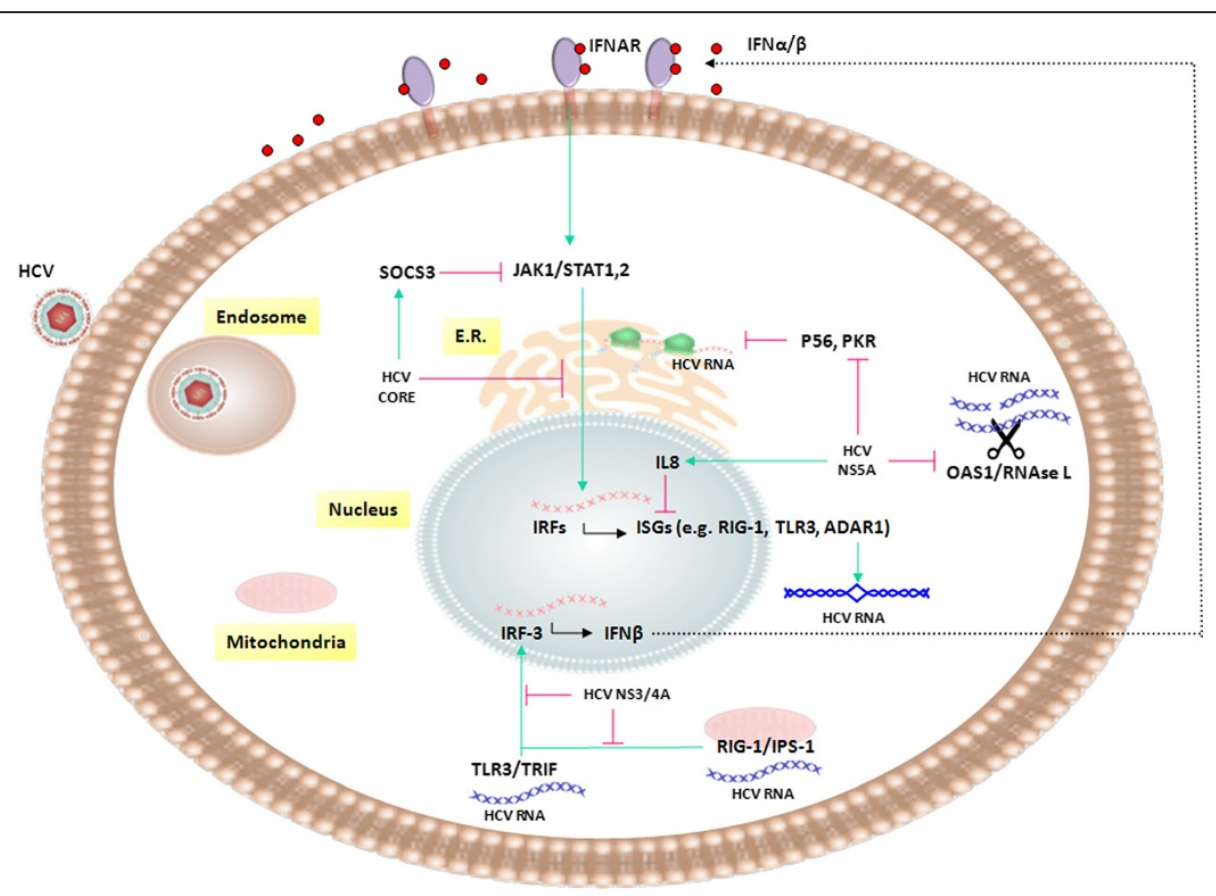

Figure 1 Modulation of innate immune response by HCV. Effects of different HCV factors, RNA or proteins, on cellular mediators of innate immune anti-viral activity are schematically represented. 
immune response and to evade antiviral defenses. A major strategy employed by HCV to subvert the host innate immune response is to undermine IFN antiviral activity [80] as well as functions of innate immune cells.

Regarding the IFN activity, the main targets of $\mathrm{HCV}$ are represented by the PAMP signalling pathways leading to IRF-3 activation, the IFN- $\alpha / \beta$ receptor signalling pathway and the ISG effector proteins (Figure 1). In particular, HCV NS3/4A protein cleaves the adaptor molecules TRIF and IPS-1, thereby blocking TLR3 and RIG-I signalling pathways [81]. Moreover, the HCV core protein interferes with JAK/STAT signalling and ISGs expression by several strategies, including 1) inhibition and degradation of STAT1 [82]; 2) induction of the suppressor of cytokine signaling 3 (SOCS3) and protein phosphatase 2A (PP2A), which are an inhibitor of the JAK/STAT pathway [83] and a reducer of the transcriptional activity of ISG factor 3 (ISGF3) [84], respectively; 3) inhibition of ISGF3 binding to IFN-stimulated response elements (ISRE).

Furthermore, several $\mathrm{HCV}$ proteins directly interfere with the function of ISGs. Indeed, functional genomics analyses have shown that the NS5A protein induces a general attenuation of ISG expression via an increased secretion of IL-8 [85] and a subsequent modulation of IFN functions. In support of such inhibitory mechanism, serum levels of IL-8 have been found elevated in patients with chronic hepatitis C. In addition, NS5A inhibits $2^{\prime}-5^{\prime}$ oligoadenylate synthetase (2/-5/ OAS) and PKR function [86] and E2 acts as decoy target to PKR [87].

Even though such escape strategies still need to be validated in vivo, the available data strongly suggest that HCV has established redundant means to cope with the host IFN response.

\section{Interactions between HCV and cellular compartments of innate immunity}

More recently, several reports have suggested that $\mathrm{HCV}$ itself may actively suppress the host immune response by inhibiting the function of innate immune cells.

\section{NK cells}

NK cell activation, during the early phase of HCV infection, is involved in viral eradication, whereas direct suppression of NK cells may be implicated in HCV chronic persistence [88]. It has been reported that the binding of HCV E2 protein to the CD81 receptor on NK cells inhibits their function and IFN- $\gamma$ production $[89,90]$. Such results, however, are still controversial and their biological significance in vivo needs to be verified, considering that HCV E2 does not efficiently crosslink CD81 on NK cells when it is part of infectious virions, and NK cell function is not impaired after in vitro exposure to high concentrations of cell culture-produced HCV [91].
The HCV core protein induces an up-regulation in the expression of major histocompatibility complex (MHC) class I molecules on the surface of hepatocytes by increasing the expression of transporter associated with antigen processing 1 (TAP1). The resulting suppression of NK cells activation and cytotoxic activity significantly contribute to $\mathrm{HCV}$ persistence [92].

In addition, it has been reported that NK cells from chronic $\mathrm{HCV}$-infected individuals show an increased expression of CD94/NKG2A inhibitory receptor, as well as production of immunosuppressive IL-10 and TGF $\beta$. The sum of these effects is the functional impairment of NK cells to activate DCs and, ultimately, to generate Th1 CD4+ T cells [93].

\section{DC cells}

DC response to $\mathrm{HCV}$ in the early stage of infection is crucial in determining the outcome of the disease and several studies indicate that chronic $\mathrm{HCV}$-infected individuals show an impaired function of DC subsets.

The frequency of circulating pDCs [94], as well as their ability to produce IFN- $\alpha$ upon in vitro stimulation [95] are reduced in chronic $\mathrm{HCV}$ patients and different mechanisms have been proposed. HCV core and NS3 proteins have been shown to activate in vitro monocytes via TLR2 to produce TNF- $\alpha$, which in turn inhibits IFN- $\alpha$ production and induces pDCs apoptosis [96]. Alternatively, HCV may directly inhibit IFN- $\alpha$ production by pDCs in vitro [97].

Similarly, maturation and functional differentiation of cDCs are altered in HCV infection, with decreased IL-12 and increased IL-10 production in vitro $[98,99]$, possibly resulting in insufficient $\mathrm{T}$ cell priming and delayed HCVspecific $\mathrm{T}$ cell responses. However, the impaired allostimulatory capacity of $\mathrm{cDCs}$ in chronic $\mathrm{HCV}$ patients is still contradictory, being described in some [100-102] but not all studies [103].

For both subsets of DCs, indeed, functional defects have been observed in vitro upon stimulation with individual $\mathrm{HCV}$ proteins but do not reflect an immune compromised status in chronic HCV patients, who show normal responsiveness to other viruses or recall antigens (reviewed in $[104,105])$. Therefore, the impaired efficacy of DCs compartment (i.e. pDCs) in chronic HCV patients would not be due to a "primary" dysfunction of such cells in producing type I IFNs but, more likely, to a "secondary" non-responsiveness of target $\mathrm{HCV}$-infected hepatocytes, given the capacity of HCV to inhibit the IFN-stimulated signal pathway.

Overall data suggest that $\mathrm{HCV}$ interacts with and affects the function of different actors of the innate immunity. $\mathrm{HCV}$ interference is diverse with regard to cellular levels, targets and outcomes, however, the overall disruption of the coordinated activity of the innate immune response 
results in deficient adaptive immune response and prevention of pathogen elimination (Figure 2).

\section{HCV disease: a microarray's view}

The interplay between $\mathrm{HCV}$ and innate immunity can nowadays be addressed and studied by systems biology approaches which provide detailed level of investigation to better and fully analyze the network of interactions within virus and innate immunity. Conversely to traditional "reductionist" approach, indeed, the paradigm of systems biology is to look at a biological system as a whole, evaluating interactions among biological elements and their relationship with the surrounding environment. Systems biology has been increasingly applied to oncology [106-108], autoimmunity and infections $[109,110]$ and only recently to vaccinology [111-113].

Microarray analyses of gene transcriptional profiles have been performed to identify molecular signatures of the innate immunity compartment related to $\mathrm{HCV}$ infection (Table 1).

It has been recently shown that specific immune genes are significantly increased in HCV cirrhotic liver as compared to control normal tissue [114]. Such genes include IRF1, tripartite motif-containing 22 (TRIM22), and multiple leukocyte immunoglobulin-like receptors (LILRA1, LILRA4, LILRA5, LILRB2, LILRB3 and LILRB4), which have been reported to play a role in the virus - host interaction.

IRF1 is a critical transcriptional regulatory factor that modulates ISG expression and has been shown to regulate
HCV subgenomic replicon activity in cultured hepatoma cells [115]. Interestingly, polymorphisms in the IRF1 promoter have been associated with a better response to IFN- $\alpha$ therapy in patients with chronic HCV infection [116].

TRIM22 belongs to the tripartite motif family of proteins which have been associated with innate immune response to viruses, inhibiting viral replication [117].

Moreover, multiple leukocyte immunoglobulin like receptors (LILRs) are known to be expressed on myelomonocytic cells and can influence both the innate and acquired immune response. In particular, LILRB2 has been previously reported to be up-regulated also in HIV patients and may impair the antigen presentation function of monocytes [118], whereas, LILRB4 has been shown to impair antigen presentation and $\mathrm{T}$ cell recruitment modulating the expression of proinflammatory cytokines [119].

A different study showed a total of 524 genes differentially expressed in "advanced HCV" as compared to non viral hepatitis, with 466 up-regulated genes and 58 down-regulated genes [120]. The most affected biological functions observed in "advanced HCV" include the canonical pathways of calcium signalling, hepatic fibrosis/stellate cell activation and actin cytoskeleton signalling. Moreover, many differentially expressed genes involved in the pathways of immune system, fibrosis, proliferation, cell growth, and apoptosis have been found to be up-regulated according to previously published data [121-123]. The majority of such genes are involved in the pathway of the immune and inflammatory response, including: class II major histocompatibility



Figure 2 Interactions between HCV and target cells. Effects of the HCV infection on hepatocytes as well as cells of the innate immunity have been described. Inhibitory strategies (confirmed and contradictory) employed by individual HCV proteins have been indicated. 
Table 1 Differentially expressed genes identified in listed studies on liver tissues from chronic HCV patients GENE NAME DESCRIPTION

\begin{tabular}{|c|c|}
\hline \multicolumn{2}{|c|}{ Folkers et al. [114] } \\
\hline IFNAR1 & Interferon-alpha/beta receptor alpha chain Precursor \\
\hline IRF1 & Interferon regulatory factor 1 \\
\hline LAIR1 & Leukocyte-associated immunoglobulin-like receptor 1 Precursor \\
\hline LEAP2 & Liver-expressed antimicrobial peptide 2 Precursor \\
\hline LILRA1 & Leukocyte immunoglobulin-like receptor subfamily A member 1 Precursor \\
\hline LILRA4 & Leukocyte immunoglobulin-like receptor subfamily A member 4 Precursor \\
\hline LILRA5 & Leukocyte immunoglobulin-like receptor subfamily A member 5 Precursor \\
\hline LILRB2 & Leukocyte immunoglobulin-like receptor subfamily B member 2 Precursor \\
\hline LILRB3 & Leukocyte immunoglobulin-like receptor subfamily B member 3 Precursor \\
\hline LILRB4 & Leukocyte immunoglobulin-like receptor subfamily B member 4 Precursor \\
\hline MAP4K2 & Mitogen-activated protein kinase 2 \\
\hline PSMB4 & Proteasome subunit beta type-4 Precursor \\
\hline RFX5 & DNA-binding protein RFX5 \\
\hline TRIM22 & Tripartite motif-containing protein 22 \\
\hline TRIM34 & Tripartite motif-containing protein 34 \\
\hline \multicolumn{2}{|c|}{ Khalid et al. [138] } \\
\hline CCR4 & Chemokine receptor 4 \\
\hline$\overline{C X C L 10}$ & Chemokine ligand 10 \\
\hline HLA DQß1 & Major histocompatibility complex II DQ beta1 \\
\hline HLA DQX1 & Major histocompatibility complex II DQ alpha1 \\
\hline IFI16 & IFNa induced protein 16 \\
\hline IGLL & Immunoglobulin lambda locus \\
\hline IL2RA & Interleukin 2 receptor alpha \\
\hline LGALS3 & Lectine galactoside binding soluble 3 \\
\hline SCYA19 & Small inducible cytokine subfamily A \\
\hline SGK & Serum/glucocorticoid regulated kinase \\
\hline \multicolumn{2}{|c|}{ Blackham et al. [139] } \\
\hline $\mathrm{CXCL1}$ & Chemokine ligand 1 \\
\hline CXCL16 & Chemokine ligand 16 \\
\hline CXCL2 & Chemokine ligand 2 \\
\hline $\mathrm{CXCL3}$ & Chemokine ligand 3 \\
\hline CXCL5 & Chemokine ligand 5 \\
\hline CXCL6 & Chemokine ligand 6 \\
\hline $\mathrm{IL}-8$ & Interleukin 8 \\
\hline IRF1 & Interferon regulatory factor 1 \\
\hline IRF9 & Interferon regulatory factor 9 \\
\hline MASP1 & Mannan-binding lectin serine protease 1 \\
\hline MBL2 & Mannose-binding lectin (protein C) 2, soluble \\
\hline $\mathrm{MX1}$ & Interferon-induced GTP-binding protein Mx1 \\
\hline SOCS2 & Suppressor of cytokine signaling 2 \\
\hline SOCS3 & Suppressor of cytokine signaling 3 \\
\hline \multicolumn{2}{|c|}{ De Giorgi et al. [128] } \\
\hline$\underline{B 2 M}$ & Beta 2 microglobulin \\
\hline CD7 & CD7 molecule \\
\hline HLAF & Major histocompatibility complex, class I, F \\
\hline IFI16 & IFNa induced protein 16 \\
\hline
\end{tabular}


Table 1 Differentially expressed genes identified in listed studies on liver tissues from chronic HCV patients (Continued)

\begin{tabular}{ll}
\hline IFI27 & IFNa induced protein 27 \\
\hline OASL & 2/-5/-oligoadenylate synthetase-like protein \\
\hline PSMB9 & Proteasome subunit beta type-9 \\
\hline PSME2 & Proteasome activator subunit 2 \\
\hline STAT & Signal transducer and activator of transcription 1, 91 kDa \\
\hline TAP1 & Transporter 1, ATP-binding cassette, sub-family B (MDR/TAP) \\
\hline
\end{tabular}

complex HLADQa1, HLADRa1, chemokines and chemokine receptors [124].

Moreover, a microarray analysis performed on Huh7 hepatocarcinoma cell line demonstrated that infection with $\mathrm{HCV}$ JFH-1 viral particles alters the expression of host genes involved in cellular defense mechanisms that protect the cell against infection and oxidative stress which, in turn, determine the fate of cellular survival [125]. Furthermore, HCV JFH-1 infection is able to stimulate the expression of proinflammatory antiviral response genes, including those involved in type I and II interferon responses (e.g. IRF1, IRF9, and myxovirus (influenza virus) resistance 1, interferon-inducible protein p78 (mouse) (MX1) genes), the complement cascade (e.g. mannosebinding lectin (MBL) 2 and mannose-binding protein associated serine protease (MASP) 1 genes), and the production of proinflammatory chemokines and cytokines (e.g. IL-8 and CXC chemokine ligand (CXCL) 1,-2,-3,-5, -6 , and-16 genes) [126]. Increased expression of genes encoding for negative regulators of the interferon response has been also observed, including several members of the SOCS gene family (e.g., SOCS2 and -3 genes) [127].

In this framework, our group evaluated differential gene expression by microarray analysis on liver biopsies obtained from chronic $\mathrm{HCV}$ and control negative patients [128]. Unique gene signatures were identified and, in particular, the $\mathrm{HCV}$ infected liver tissue showed strong up-regulation of genes involved in antigen presentation, protein ubiquitination, interferon signaling, IL-4 signalling, bacteria and viruses cell cycle and chemokine IL-4 signalling pathways.

Data analysis focused on the expression levels of specific genes related to the innate immunity pathway showed a strong up-regulation of genes involved, at multiple levels, in the pathway of Type I IFN signalling, including the STAT1 transcription factor and the downstream regulated genes (ISGs), in agreement to studies from other groups [129].

Among the observed up-regulated ISGs, gammainterferon-inducible protein 16 (IFI16), interferon alphainducible protein 27 (IFI27) and 2'-5'-oligoadenylate synthase-like (OASL) were identified. In particular, IFI16 controls cellular proliferation by modulating the functions of cell cycle regulatory factors including p53/TP53 and the retinoblastoma protein $(\mathrm{pRb})[130,131]$. IFI27 is known to promote cell death, triggering an IFN-induced apoptosis with robust release of cytochrome $C$ from the mitochondria and activation of BCL2-associated X protein (BAX) and caspases 2, 3, 6, 8 and 9 [132]. Furthermore, the $2^{\prime}-5^{\prime}$ oligoadenylate synthase-like protein (OASL) has been shown to bind double-stranded RNA and DNA, suggesting a role in anti-viral activity [133].

Moreover, MHC components of antigen processing and presentation such as HLA-F, Beta-2-microglobulin (B2M), CD7 and TAP1, have been found up-regulated in HCVpositive liver tissue. In particular, TAP1 is involved in the transport of antigens from the cytoplasm to the endoplasmic reticulum for association with MHC class I molecules [134]. Indeed, it is well known that HCV core protein enhances MHC class I molecule function, by increasing the expression of TAP1, thus contributing to $\mathrm{HCV}$ persistence by suppressing the cytotoxic activity of NK cells [135].

Furthermore, data analysis focused on the expression levels of specific genes related to the innate immunity pathway show a relevant activation trend of the flagellindependent TLR5, associated with the activation of IRAK1 (variant 3) and decreased level of IL-10 and IL-1b (submitted for publication).

Such overall data shed light on specific pathogenetic mechanisms and gene signatures involved in HCV-related disease and suggest the relevant role of innate immunity in progression of HCV infection. Furthermore, the analysis of relevant pathways and specific genes involved in $\mathrm{HCV}$ progression to cancer may have a relevant impact on the early identification of "progressors" to select for appropriate therapeutic actions.

Indeed, despite advances have been made in the treatment of HCV chronic infection with the combination of pegylated interferon (PEG-IFN) and ribavirin, treatment failure still occurs in about half of the patients and prediction of treatment response would be of great value.

In this perspective, several studies employed gene expression profiling analysis to investigate the molecular basis for treatment failure in $\mathrm{HCV}$ chronic infection.

In particular, a systems biology approach using highthroughput technologies, such as complementary DNA microarrays combined with mathematical modeling, was 
applied to identify a liver gene signature to predict sustained virological response to PEG-IFN plus ribavirin in patients with HCV chronic hepatitis [136,137].

To this aim, expression profiling analysis was performed on liver biopsy specimens taken before therapy and gene expression levels were compared among 15 nonresponders (NR), 16 responders (R), and 20 healthy subjects.

Eighteen genes were differentially expressed between responders and nonresponders. Up-regulation of a specific set of IFN-responsive genes predicted poor response to therapy, suggesting a possible rationale for treatment resistance.

In particular, upregulation of the following 8 genes showed the most consistent ability to classify NR and R subjects: ISG15, activating transcription factor 5 (ATF5), IFN-induced protein with tetratricopeptide repeats (IFIT1), MX1, ubiquitin-specific protease 18 (USP18), dual specificity phosphatase 1 (DUSP1), cyclin E binding protein (CEB1) and 40S ribosomal protein S28 (RPS28). Overall, the study showed that different innate IFN response to $\mathrm{HCV}$ infection may significantly impact on the responsiveness to PEG-IFN plus ribavirin therapy and identify NR and $R$ patients [137].

\section{Conclusions}

The host immune response plays a critical role in HCV infection because of its potential to contribute not only to viral clearance but also to liver injury. $\mathrm{HCV}$ attenuates both innate and adaptive immune responses, thereby reducing the viral clearance as well as the degree of immunemediated liver injury, allowing coexistence of both virus and host. Key questions for future studies remain for nearly every aspect of the host immune response; so far, the pathogenetic mechanisms involved in progression to distinct HCV-related malignant tumors are still ill defined.

However, the analysis of the innate immune pathways involved in $\mathrm{HCV}$ chronic infection would help elucidating the possible mechanisms leading to $\mathrm{HCV}$ related cancers, such as HCC or B-cell NHL.

Future studies focused on the analysis of relevant pathways and specific genes involved in HCV infection and progression to cancer would have a relevant impact on the understanding of $\mathrm{HCV}$-related carcinogenesis (HCC and/or B cell NHL) as well as on the management of HCV-infected subjects, making easier the identification of "progressors" to select for appropriate preventive/therapeutic actions.

\section{Competing interests}

The authors declare that they have no competing interests.

\section{Authors' contributions}

LB and AP drafted the manuscript. MLT participated in the draft of the manuscript. FMB conceived of the study and participated in its design and coordination and helped to draft the manuscript. All authors read and approved the final manuscript.
Received: 18 January 2012 Accepted: 24 February 2012

Published: 26 March 2012

\section{References}

1. Levrero M: Viral hepatitis and liver cancer: the case of hepatitis C. Oncogene 2006, 25:3834-3847.

2. Ferri C, Longombardo G, La CL, Greco F, Lombardini F, Cecchetti R, Cagianelli MA, Marchi S, Monti M, Zignego AL: Hepatitis C virus chronic infection as a common cause of mixed cryoglobulinaemia and autoimmune liver disease. J Intern Med 1994, 236:31-36.

3. Ferri C, Caracciolo F, Zignego AL, La CL, Monti M, Longombardo G, Lombardini F, Greco F, Capochiani E, Mazzoni A: Hepatitis C virus infection in patients with non-Hodgkin's lymphoma. Br J Haematol 1994, 88:392-394

4. De Re V, Caggiari L, Simula MP, De VS, Sansonno D, Dolcetti R: B-cell lymphomas associated with HCV infection. Gastroenterology 2007, 132:1205-1207.

5. Choo QL, Richman KH, Han JH, Berger K, Lee C, Dong C, Gallegos C, Coit D, Medina-Selby R, Barr PJ: Genetic organization and diversity of the hepatitis C virus. Proc Natl Acad Sci U S A 1991, 88:2451-2455.

6. Irshad M, Ansari MA, Singh A, Nag P, Raghvendra L, Singh S, Badhal SS: HCV-genotypes: a review on their origin, global status, assay system, pathogenecity and response to treatment. Hepatogastroenterology 2010, 57:1529-1538

7. Fishman SL, Branch AD: The quasispecies nature and biological implications of the hepatitis C virus. Infect Genet Evol 2009, 9:1158-1167.

8. Han JH, Shyamala V, Richman KH, Brauer MJ, Invine B, Urdea MS, Tekamp-Olson P, Kuo G, Choo QL, Houghton M: Characterization of the terminal regions of hepatitis C viral RNA: identification of conserved sequences in the 5/ untranslated region and poly(A) tails at the 3 / end. Proc Natl Acad Sci U S A 1991, 88:1711-1715.

9. Shi ST, Lai MMC: HCV 5/ and 3/UTR: When Translation Meets Replication. 2006.

10. Dutkiewicz M, Swiqtkowska A, Ciesiolka J: Structure and function of the non-coding regions of hepatitis C viral RNA. Postepy Biochem 2006, 52:62-71.

11. Suzuki T: Assembly of hepatitis C virus particles. Microbiol Immunol 2011, 55:12-18.

12. Choo QL, Richman KH, Han JH, Berger K, Lee C, Dong C, Gallegos C, Coit D, Medina-Selby R, Barr PJ: Genetic organization and diversity of the hepatitis C virus. Proc Natl Acad Sci U S A 1991, 88:2451-2455.

13. Zhang J, Randall G, Higginbottom A, Monk P, Rice CM, McKeating JA: CD81 is required for hepatitis $C$ virus glycoprotein-mediated viral infection. J Virol 2004, 78:1448-1455.

14. Scarselli E, Ansuini H, Cerino R, Roccasecca RM, Acali S, Filocamo G, Traboni C, Nicosia A, Cortese R, Vitelli A: The human scavenger receptor class B type I is a novel candidate receptor for the hepatitis C virus. EMBO J 2002, 21:5017-5025.

15. Evans MJ, Von HT, Tscherne DM, Syder AJ, Panis M, Wolk B, Hatziioannou T, McKeating JA, Bieniasz PD, Rice CM: Claudin-1 is a hepatitis C virus co-receptor required for a late step in entry. Nature 2007, 446:801-805.

16. Zheng A, Yuan F, Li Y, Zhu F, Hou P, Li J, Song X, Ding M, Deng H: Claudin- 6 and claudin-9 function as additional coreceptors for hepatitis C virus. J Virol 2007, 81:12465-12471.

17. Liu S, Yang W, Shen L, Turner JR, Coyne CB, Wang T: Tight junction proteins claudin- 1 and occludin control hepatitis $C$ virus entry and are downregulated during infection to prevent superinfection. J Virol 2009, 83:2011-2014

18. Barth H, Rybczynska J, Patient R, Choi Y, Sapp RK, Baumert TF, Krawczynski K, Liang TJ: Both innate and adaptive immunity mediate protective immunity against hepatitis $\mathrm{C}$ virus infection in chimpanzees. Hepatology 2011

19. Hiroishi $K$, Ito $T$, Imawari M: Immune responses in hepatitis $C$ virus infection and mechanisms of hepatitis C virus persistence. J Gastroenterol Hepatol 2008, 23:1473-1482.

20. Chang KM: Immunopathogenesis of hepatitis C virus infection. Clin Liver Dis 2003, 7:89-105.

21. Gerlach JT, Diepolder HM, Jung MC, Gruener NH, Schraut WW, Zachoval R, Hoffmann R, Schirren CA, Santantonio T, Pape GR: Recurrence of hepatitis $C$ virus after loss of virus-specific CD4(+) T-cell response in acute hepatitis C. Gastroenterology 1999, 117:933-941. 
22. Shin EC, Park SH, Demino M, Nascimbeni M, Mihalik K, Major M, Veerapu NS, Heller T, Feinstone SM, Rice CM, Rehermann B: Delayed Induction, Not Impaired Recruitment of Specific CD8(+) T Cells, Causes the Late Onset of Acute Hepatitis C. Gastroenterology 2011.

23. Hiroishi $K$, Ito $T$, Imawari $M$ : Immune responses in hepatitis $C$ virus infection and mechanisms of hepatitis $C$ virus persistence. J Gastroenterol Hepatol 2008, 23:1473-1482.

24. Banchereau J, Steinman RM: Dendritic cells and the control of immunity. Nature 1998, 392:245-252.

25. Siegal FP, Kadowaki N, Shodell M, Fitzgerald-Bocarsly PA, Shah K, Ho S, Antonenko S, Liu YJ: The nature of the principal type 1 interferonproducing cells in human blood. Science 1999, 284:1835-1837.

26. Matsui T, Connolly JE, Michnevitz M, Chaussabel D, Yu Cl, Glaser C, Tindle S, Pypaert M, Freitas H, Piqueras B, Banchereau J, Palucka AK: CD2 distinguishes two subsets of human plasmacytoid dendritic cells with distinct phenotype and functions. J Immunol 2009, 182:6815-6823.

27. Dolganiuc A, Chang S, Kodys K, Mandrekar P, Bakis G, Cormier M, Szabo G: Hepatitis $C$ virus (HCV) core protein-induced, monocyte-mediated mechanisms of reduced IFN-alpha and plasmacytoid dendritic cell loss in chronic HCV infection. J Immunol 2006, 177:6758-6768.

28. Kanto T, Hayashi N, Takehara T, Tatsumi T, Kuzushita N, Ito A, Sasaki Y, Kasahara A, Hori M: Impaired allostimulatory capacity of peripheral blood dendritic cells recovered from hepatitis $C$ virus-infected individuals. J Immunol 1999, 162:5584-5591.

29. Kanto T, Inoue M, Miyatake H, Sato A, Sakakibara M, Yakushijin T, Oki C, Itose I, Hiramatsu N, Takehara T, Kasahara A, Hayashi N: Reduced numbers and impaired ability of myeloid and plasmacytoid dendritic cells to polarize T helper cells in chronic hepatitis C virus infection. J Infect Dis 2004, 190:1919-1926.

30. Kadowaki N, Ho S, Antonenko S, Malefyt RW, Kastelein RA, Bazan F, Liu YJ: Subsets of human dendritic cell precursors express different toll-like receptors and respond to different microbial antigens. J Exp Med 2001, 194:863-869.

31. Heufler C, Koch F, Stanzl U, Topar G, Wysocka M, Trinchieri G, Enk A, Steinman RM, Romani N, Schuler G: Interleukin-12 is produced by dendritic cells and mediates T helper 1 development as well as interferon-gamma production by T helper 1 cells. Eur J Immunol 1996, 26:659-668.

32. Pape GR, Gerlach TJ, Diepolder HM, Gruner N, Jung M, Santantonio T: Role of the specific T-cell response for clearance and control of hepatitis C virus. J Viral Hepat 1999, 6(Suppl 1):36-40.

33. Wertheimer AM, Bakke A, Rosen HR: Direct enumeration and functional assessment of circulating dendritic cells in patients with liver disease. Hepatology 2004, 40:335-345

34. Kanto T, Inoue M, Miyatake H, Sato A, Sakakibara M, Yakushijin T, Oki C, Itose I, Hiramatsu N, Takehara T, Kasahara A, Hayashi N: Reduced numbers and impaired ability of myeloid and plasmacytoid dendritic cells to polarize T helper cells in chronic hepatitis C virus infection. J Infect Dis 2004, 190:1919-1926.

35. Chan SH, Perussia B, Gupta JW, Kobayashi M, Pospisil M, Young HA, Wolf SF, Young D, Clark SC, Trinchieri G: Induction of interferon gamma production by natural killer cell stimulatory factor: characterization of the responder cells and synergy with other inducers. J Exp Med 1991, 173:869-879.

36. Khakoo SI, Thio CL, Martin MP, Brooks CR, Gao X, Astemborski J, Cheng J, Goedert JJ, Vlahov D, Hilgartner M, Cox S, Little AM, Alexander GJ, Cramp ME, O'Brien SJ, Rosenberg WM, Thomas DL, Carrington M: HLA and NK cell inhibitory receptor genes in resolving hepatitis $C$ virus infection. Science 2004, 305:872-874.

37. Ahlenstiel G, Martin MP, Gao X, Carrington M, Rehermann B: Distinct KIR/ HLA compound genotypes affect the kinetics of human antiviral natural killer cell responses. J Clin Invest 2008, 118:1017-1026.

38. Hiroishi $K$, Ito T, Imawari $M$ : Immune responses in hepatitis $C$ virus infection and mechanisms of hepatitis $C$ virus persistence. J Gastroenterol Hepatol 2008, 23:1473-1482.

39. Parker GA, Picut CA: Liver immunobiology. Toxicol Pathol 2005, 33:52-62.

40. Akira $\mathrm{S}, \mathrm{Hemmi} \mathrm{H}$ : Recognition of pathogen-associated molecular patterns by TLR family. Immunol Lett 2003, 85:85-95

41. Saito T, Gale M Jr: Principles of intracellular viral recognition. Curr Opin Immunol 2007, 19:17-23
42. Saito T, Gale M Jr: Regulation of innate immunity against hepatitis $C$ virus infection. Hepatol Res 2008, 38:115-122.

43. Saito T, Hirai R, Loo YM, Owen D, Johnson CL, Sinha SC, Akira S, Fujita T, Gale M Jr: Regulation of innate antiviral defenses through a shared repressor domain in RIG-I and LGP2. Proc Natl Acad Sci U S A 2007 104:582-587.

44. Eksioglu EA, Zhu H, Bayouth L, Bess J, Liu HY, Nelson DR, Liu C: Characterization of HCV Interactions with Toll-Like Receptors and RIG-I in Liver Cells. PLoS One 2011, 6:e21186.

45. Franchi L, McDonald C, Kanneganti TD, Amer A, Nunez G: Nucleotidebinding oligomerization domain-like receptors: intracellular pattern recognition molecules for pathogen detection and host defense. J Immunol 2006, 177:3507-3513.

46. Imler JL, Hoffmann JA: Toll and Toll-like proteins: an ancient family of receptors signaling infection. Rev Immunogenet 2000, 2:294-304.

47. Tsan MF: Toll-like receptors, inflammation and cancer. Semin Cancer Biol 2006, 16:32-37.

48. Takeda K, Kaisho T, Akira S: Toll-like receptors. Annu Rev Immunol 2003, 21:335-376.

49. Tsan MF: Toll-like receptors, inflammation and cancer. Semin Cancer Biol 2006, 16:32-37.

50. Kopp E, Medzhitov R: Recognition of microbial infection by Toll-like receptors. Curr Opin Immunol 2003, 15:396-401.

51. Dolganiuc A, Garcia C, Kodys K, Szabo G: Distinct Toll-like receptor expression in monocytes and T cells in chronic HCV infection. World J Gastroenterol 2006, 12:1198-1204

52. Feldmann G, Nischalke HD, Nattermann J, Banas B, Berg T, Teschendorf C, Schmiegel W, Duhrsen U, Halangk J, Iwan A, Sauerbruch T, Caselmann WH, Spengler $U$ : Induction of interleukin- 6 by hepatitis $C$ virus core protein in hepatitis C-associated mixed cryoglobulinemia and B-cell non-Hodgkin's lymphoma. Clin Cancer Res 2006, 12:4491-4498.

53. Chiron D, Bekeredjian-Ding I, Pellat-Deceunynck C, Bataille R, Jego G: Toll-like receptors: lessons to learn from normal and malignant human $B$ cells. Blood 2008, 112:2205-2213.

54. Tsan MF: Toll-like receptors, inflammation and cancer. Semin Cancer Biol 2006, 16:32-37.

55. Akira S, Takeda K: Toll-like receptor signalling. Nat Rev Immunol 2004, 4:499-511.

56. Takeda K, Akira S: TLR signaling pathway. Semin Immunol 2004, 16:3-9.

57. Tsan MF: Toll-like receptors, inflammation and cancer. Semin Cancer Biol 2006, 16:32-37.

58. Yamamoto M, Sato S, Hemmi H, Sanjo H, Uematsu S, Kaisho T, Hoshino K, Takeuchi O, Kobayashi M, Fujita T, Takeda K, Akira S: Essential role for TIRAP in activation of the signalling cascade shared by TLR2 and TLR4. Nature 2002, 420:324-329.

59. Yamamoto M, Sato S, Hemmi H, Hoshino K, Kaisho T, Sanjo H, Takeuchi O, Sugiyama M, Okabe M, Takeda K, Akira S: Role of adaptor TRIF in the MyD88-independent toll-like receptor signaling pathway. Science 2003, 301:640-643.

60. Gitlin L, Barchet W, Gilfillan S, Cella M, Beutler B, Flavell RA, Diamond MS, Colonna M: Essential role of mda-5 in type I IFN responses to polyriboinosinic:polyribocytidylic acid and encephalomyocarditis picornavirus. Proc Natl Acad Sci U S A 2006, 103:8459-8464.

61. Yoneyama M, Fujita T: RIG-I: critical regulator for virus-induced innate immunity. Tanpakushitsu Kakusan Koso 2004, 49:2571-2578.

62. Breiman A, Grandvaux N, Lin R, Ottone C, Akira S, Yoneyama M, Fujita T, Hiscott J, Meurs EF: Inhibition of RIG-I-dependent signaling to the interferon pathway during hepatitis $C$ virus expression and restoration of signaling by IKKepsilon. J Virol 2005, 79:3969-3978.

63. Foy E, Li K, Sumpter R Jr, Loo YM, Johnson CL, Wang C, Fish PM, Yoneyama M, Fujita T, Lemon SM, Gale M Jr: Control of antiviral defenses through hepatitis $\mathrm{C}$ virus disruption of retinoic acid-inducible gene-I signaling. Proc Natl Acad Sci U S A 2005, 102:2986-2991.

64. Sumpter R Jr, Loo YM, Foy E, Li K, Yoneyama M, Fujita T, Lemon SM, Gale M $\mathrm{Jr}$ : Regulating intracellular antiviral defense and permissiveness to hepatitis $C$ virus RNA replication through a cellular RNA helicase, RIG-I. J Virol 2005, 79:2689-2699.

65. Kato H, Takeuchi O, Sato S, Yoneyama M, Yamamoto M, Matsui K, Uematsu S, Jung A, Kawai T, Ishii KJ, Yamaguchi O, Otsu K, Tsujimura T, Koh CS, Reis e Sousa, Matsuura Y, Fujita T, Akira S: Differential roles of MDA5 and RIG-I helicases in the recognition of RNA viruses. Nature 2006, 441:101-105. 
66. Yoneyama M, Kikuchi M, Matsumoto K, Imaizumi T, Miyagishi M, Taira K, Foy E, Loo YM, Gale M Jr, Akira S, Yonehara S, Kato A, Fujita T: Shared and unique functions of the DExD/H-box helicases RIG-I, MDA5, and LGP2 in antiviral innate immunity. J Immunol 2005, 175:2851-2858.

67. Saito T, Hirai R, Loo YM, Owen D, Johnson CL, Sinha SC, Akira S, Fujita T, Gale M Jr: Regulation of innate antiviral defenses through a shared repressor domain in RIG-I and LGP2. Proc Natl Acad Sci U S A 2007, 104:582-587.

68. Venkataraman T, Valdes M, Elsby R, Kakuta S, Caceres G, Saijo S, Iwakura Y, Barber GN: Loss of DExD/H box RNA helicase LGP2 manifests disparate antiviral responses. J Immunol 2007, 178:6444-6455.

69. Kawai T, Akira S: Toll-like receptor and RIG-I-like receptor signaling. Ann N Y Acad Sci 2008, 1143:1-20.

70. Kawai T, Akira S: Toll-like receptor and RIG-I-like receptor signaling Ann N Y Acad Sci 2008, 1143:1-20.

71. Bigger CB, Brasky KM, Lanford RE: DNA microarray analysis of chimpanzee liver during acute resolving hepatitis C virus infection. J Virol 2001, 75:7059-7066.

72. Chen L, Borozan I, Feld J, Sun J, Tannis LL, Coltescu C, Heathcote J, Edwards AM, McGilvray ID: Hepatic gene expression discriminates responders and nonresponders in treatment of chronic hepatitis $C$ viral infection. Gastroenterology 2005, 128:1437-1444.

73. Guo JT, Sohn JA, Zhu Q, Seeger C: Mechanism of the interferon alpha response against hepatitis C virus replicons. Virology 2004, 325:71-81.

74. Taylor DR, Puig M, Darnell ME, Mihalik K, Feinstone SM: New antiviral pathway that mediates hepatitis $C$ virus replicon interferon sensitivity through ADAR1. J Virol 2005, 79:6291-6298.

75. Wang C, Pflugheber J, Sumpter R Jr, Sodora DL, Hui D, Sen GC, Gale M Jr: Alpha interferon induces distinct translational control programs to suppress hepatitis C virus RNA replication. J Virol 2003, 77:3898-3912.

76. Hui DJ, Bhasker CR, Merrick WC, Sen GC: Viral stress-inducible protein p56 inhibits translation by blocking the interaction of elF3 with the ternary complex elF2.GTP.Met-tRNAi. J Biol Chem 2003, 278:39477-39482.

77. Pflugheber J, Fredericksen B, Sumpter R Jr, Wang C, Ware F, Sodora DL, Gale M Jr: Regulation of PKR and IRF-1 during hepatitis $C$ virus RNA replication. Proc Natl Acad Sci U S A 2002, 99:4650-4655.

78. Wang C, Pflugheber J, Sumpter R Jr, Sodora DL, Hui D, Sen GC, Gale M Jr: Alpha interferon induces distinct translational control programs to suppress hepatitis C virus RNA replication. J Virol 2003, 77:3898-3912.

79. Agarwal SK, Wu M, Livingston CK, Parks DH, Mayes MD, Arnett FC, Tan FK: Toll-like receptor 3 upregulation by type I interferon in healthy and scleroderma dermal fibroblasts. Arthritis Res Ther 2011, 13:R3.

80. Lin W, Kim SS, Yeung E, Kamegaya Y, Blackard JT, Kim KA, Holtzman MJ, Chung RT: Hepatitis $C$ virus core protein blocks interferon signaling by interaction with the STAT1 SH2 domain. J Virol 2006, 80:9226-9235.

81. Foy E, Li K, Sumpter R Jr, Loo YM, Johnson CL, Wang C, Fish PM, Yoneyama M, Fujita T, Lemon SM, Gale M Jr: Control of antiviral defenses through hepatitis $C$ virus disruption of retinoic acid-inducible gene-I signaling. Proc Natl Acad Sci U S A 2005, 102:2986-2991.

82. Lin W, Kim SS, Yeung E, Kamegaya Y, Blackard JT, Kim KA, Holtzman MJ, Chung RT: Hepatitis C virus core protein blocks interferon signaling by interaction with the STAT1 SH2 domain. J Virol 2006, 80:9226-9235.

83. Bode JG, Ludwig S, Ehrhardt C, Albrecht U, Erhardt A, Schaper F, Heinrich PC, Haussinger D: IFN-alpha antagonistic activity of HCV core protein involves induction of suppressor of cytokine signaling-3. FASEB J 2003, 17:488-490.

84. Heim MH, Moradpour D, Blum HE: Expression of hepatitis $C$ virus proteins inhibits signal transduction through the Jak-STAT pathway. J Virol 1999, 73:8469-8475

85. Polyak SJ, Khabar KS, Paschal DM, Ezelle HJ, Duverlie G, Barber GN, Levy DE, Mukaida N, Gretch DR: Hepatitis C virus nonstructural 5A protein induces interleukin-8, leading to partial inhibition of the interferon-induced antiviral response. J Virol 2001, 75:6095-6106.

86. Gale MJ Jr, Korth MJ, Tang NM, Tan SL, Hopkins DA, Dever TE, Polyak SJ, Gretch DR, Katze MG: Evidence that hepatitis $C$ virus resistance to interferon is mediated through repression of the PKR protein kinase by the nonstructural 5A protein. Virology 1997, 230:217-227.

87. Taylor DR, Shi ST, Romano PR, Barber GN, Lai MM: Inhibition of the interferon-inducible protein kinase PKR by HCV E2 protein. Science 1999 285:107-110.

88. Ahlenstiel $G$, Rehermann B: Hepatitis $C$ virus and the threshold of natural killer cell inhibition. Hepatology 2005, 41:675-677.
89. Tseng $C T$, Klimpel $G R$ : Binding of the hepatitis $C$ virus envelope protein $E 2$ to CD81 inhibits natural killer cell functions. J Exp Med 2002, 195:43-49.

90. Crotta S, Stilla A, Wack A, D'Andrea A, Nuti S, D'Oro U, Mosca M, Filliponi F, Brunetto RM, Bonino F, Abrignani S, Valiante NM: Inhibition of natural killer cells through engagement of CD81 by the major hepatitis $C$ virus envelope protein. J Exp Med 2002, 195:35-41.

91. Yoon JC, Shiina M, Ahlenstiel G, Rehermann B: Natural killer cell function is intact after direct exposure to infectious hepatitis $C$ virions Hepatology 2009, 49:12-21.

92. Herzer K, Falk CS, Encke J, Eichhorst ST, Ulsenheimer A, Seliger B, Krammer PH: Upregulation of major histocompatibility complex class I on liver cells by hepatitis $C$ virus core protein via p53 and TAP1 impairs natural killer cell cytotoxicity. J Virol 2003, 77:8299-8309.

93. Jinushi M, Takehara T, Tatsumi T, Kanto T, Miyagi T, Suzuki T, Kanazawa $Y$, Hiramatsu N, Hayashi N: Negative regulation of NK cell activities by inhibitory receptor CD94/NKG2A leads to altered NK cell-induced modulation of dendritic cell functions in chronic hepatitis $C$ virus infection. J Immunol 2004, 173:6072-6081.

94. Decalf J, Fernandes S, Longman R, Ahloulay M, Audat F, Lefrerre F, Rice CM, Pol S, Albert ML: Plasmacytoid dendritic cells initiate a complex chemokine and cytokine network and are a viable drug target in chronic HCV patients. J Exp Med 2007, 204:2423-2437.

95. Dolganiuc A, Chang S, Kodys K, Mandrekar P, Bakis G, Cormier M, Szabo G: Hepatitis $C$ virus (HCV) core protein-induced, monocyte-mediated mechanisms of reduced IFN-alpha and plasmacytoid dendritic cell loss in chronic HCV infection. J Immunol 2006, 177:6758-6768.

96. Dolganiuc A, Chang S, Kodys K, Mandrekar P, Bakis G, Cormier M, Szabo G: Hepatitis $C$ virus (HCV) core protein-induced, monocyte-mediated mechanisms of reduced IFN-alpha and plasmacytoid dendritic cell loss in chronic HCV infection. J Immunol 2006, 177:6758-6768.

97. Yoon JC, Shiina M, Ahlenstiel G, Rehermann B: Natural killer cell function is intact after direct exposure to infectious hepatitis $C$ virions Hepatology 2009, 49:12-21.

98. Auffermann-Gretzinger S, Keeffe EB, Levy S: Impaired dendritic cell maturation in patients with chronic, but not resolved, hepatitis $C$ virus infection. Blood 2001, 97:3171-3176.

99. Dolganiuc A, Kodys K, Kopasz A, Marshall C, Do T, Romics L Jr, Mandrekar P, Zapp M, Szabo G: Hepatitis C virus core and nonstructural protein 3 proteins induce pro- and anti-inflammatory cytokines and inhibit dendritic cell differentiation. J Immunol 2003, 170:5615-5624.

100. Kanto T, Inoue M, Miyatake H, Sato A, Sakakibara M, Yakushijin T, Oki C, Itose I, Hiramatsu N, Takehara T, Kasahara A, Hayashi N: Reduced numbers and impaired ability of myeloid and plasmacytoid dendritic cells to polarize T helper cells in chronic hepatitis C virus infection. J Infect Dis 2004, 190:1919-1926.

101. Kanto T, Hayashi N, Takehara T, Tatsumi T, Kuzushita N, Ito A, Sasaki Y, Kasahara A, Hori M: Impaired allostimulatory capacity of peripheral blood dendritic cells recovered from hepatitis $C$ virus-infected individuals. J Immunol 1999, 162:5584-5591.

102. Bain C, Fatmi A, Zoulim F, Zarski JP, Trepo C, Inchauspe G: Impaired allostimulatory function of dendritic cells in chronic hepatitis $C$ infection. Gastroenterology 2001, 120:512-524.

103. Longman RS, Talal AH, Jacobson IM, Albert ML, Rice CM: Presence of functional dendritic cells in patients chronically infected with hepatitis C virus. Blood 2004, 103:1026-1029.

104. Barnaba V: Hepatitis C virus infection: a "liaison a trois" amongst the virus, the host, and chronic low-level inflammation for human survival. J Hepatol 2010, 53:752-761.

105. Albert ML, Decalf J, Pol S: Plasmacytoid dendritic cells move down on the list of suspects: in search of the immune pathogenesis of chronic hepatitis C. J Hepatol 2008, 49:1069-1078.

106. Potti A, Mukherjee S, Petersen R, Dressman HK, Bild A, Koontz J, Kratzke R, Watson MA, Kelley M, Ginsburg GS, West M, Harpole DH Jr, Nevins JR: A genomic strategy to refine prognosis in early-stage non-small-cell lung cancer. N Engl J Med 2006, 355:570-580.

107. Alizadeh AA, Staudt LM: Genomic-scale gene expression profiling of normal and malignant immune cells. Curr Opin Immunol 2000, 12:219-225.

108. Sorlie T, Perou CM, Tibshirani R, Aas T, Geisler S, Johnsen H, Hastie T, Eisen MB, van de RM, Jeffrey SS, Thorsen T, Quist H, Matese JC, Brown PO, Botstein D, Eystein LP, Borresen-Dale AL: Gene expression patterns of breast carcinomas 
distinguish tumor subclasses with clinical implications. Proc Natl Acad Sci U S A 2001, 98:10869-10874.

109. Chaussabel D, Quinn C, Shen J, Patel P, Glaser C, Baldwin N, Stichweh D, Blankenship D, Li L, Munagala I, Bennett L, Allantaz F, Mejias A, Ardura M, Kaizer E, Monnet L, Allman W, Randall H, Johnson D, Lanier A, Punaro M, Wittkowski KM, White P, Fay J, Klintmalm G, Ramilo O, Palucka AK, Banchereau J, Pascual V: A modular analysis framework for blood genomics studies: application to systemic lupus erythematosus. Immunity 2008, 29:150-164.

110. Ramilo O, Allman W, Chung W, Mejias A, Ardura M, Glaser C, Wittkowski KM, Piqueras B, Banchereau J, Palucka AK, Chaussabel D: Gene expression patterns in blood leukocytes discriminate patients with acute infections Blood 2007, 109:2066-2077.

111. Buonaguro L, Petrizzo A, Tornesello M, Napolitano M, Martorelli D, Castello G, Beneduce G, De RA, Perrella O, Romagnoli L, Sousa V, De RV, Dolcetti R, Buonaguro FM: Immune signatures in human PBMCs of idiotypic vaccine for HCV-related lymphoproliferative disorders. J Trans/ Med 2010, 8:18.

112. Buonaguro L, Pulendran B: Immunogenomics and systems biology of vaccines. Immunol Rev 2011, 239:197-208.

113. Pulendran B, Li S, Nakaya HI: Systems vaccinology. Immunity 2010, 33:516-529.

114. Folkers ME, Delker DA, Maxwell Cl, Nelson CA, Schwartz JJ, Nix DA, Hagedorn $\mathrm{CH}$ : ENCODE tiling array analysis identifies differentially expressed annotated and novel 5/ capped RNAs in hepatitis C infected liver. PLoS One 2011, 6:e14697.

115. Itsui $Y$, Sakamoto N, Kurosaki M, Kanazawa N, Tanabe $Y$, Koyama T, Takeda Y, Nakagawa M, Kakinuma S, Sekine Y, Maekawa S, Enomoto N, Watanabe M: Expressional screening of interferon-stimulated genes for antiviral activity against hepatitis C virus replication. J Viral Hepat 2006, 13:690-700

116. Wietzke-Braun P, Maouzi AB, Manhardt LB, Bickeboller H, Ramadori G, Mihm S: Interferon regulatory factor-1 promoter polymorphism and the outcome of hepatitis C virus infection. Eur J Gastroenterol Hepatol 2006, 18:991-997.

117. Nisole S, Stoye JP, Saib A: TRIM family proteins: retroviral restriction and antiviral defence. Nat Rev Microbiol 2005, 3:799-808.

118. Vlad G, Piazza F, Colovai A, Cortesini R, Della PF, Suciu-Foca N, Manavalan JS: Interleukin-10 induces the upregulation of the inhibitory receptor ILT4 in monocytes from HIV positive individuals. Hum Immunol 2003, 64:483-489.

119. Chang CC, Liu Z, Vlad G, Qin H, Qiao X, Mancini DM, Marboe CC, Cortesini $\mathrm{R}$, Suciu-Foca N: Ig-like transcript 3 regulates expression of proinflammatory cytokines and migration of activated T cells. J Immuno 2009, 182:5208-5216.

120. Khalid SS, Hamid S, Siddiqui AA, Qureshi A, Qureshi N: Gene profiling of early and advanced liver disease in chronic hepatitis $C$ patients. Hepatol Int 2011.

121. Shackel NA, McGuinness PH, Abbott CA, Gorrell MD, McCaughan GW: Insights into the pathobiology of hepatitis $C$ virus-associated cirrhosis: analysis of intrahepatic differential gene expression. Am J Pathol 2002, 160:641-654.

122. Smith MW, Yue ZN, Korth MJ, Do HA, Boix L, Fausto N, Bruix J, Carithers RL $\mathrm{Jr}$, Katze MG: Hepatitis $C$ virus and liver disease: global transcriptional profiling and identification of potential markers. Hepatology 2003, 38:1458-1467.

123. Bieche I, Asselah T, Laurendeau I, Vidaud D, Degot C, Paradis V, Bedossa P, Valla DC, Marcellin P, Vidaud M: Molecular profiling of early stage liver fibrosis in patients with chronic hepatitis C virus infection. Virology 2005, 332:130-144.

124. Khalid SS, Hamid S, Siddiqui AA, Qureshi A, Qureshi N: Gene profiling of early and advanced liver disease in chronic hepatitis $C$ patients. Hepatol Int 2011.

125. Blackham S, Baillie A, Al-Hababi F, Remlinger K, You S, Hamatake R, McGarvey MJ: Gene expression profiling indicates the roles of host oxidative stress, apoptosis, lipid metabolism, and intracellular transport genes in the replication of hepatitis C virus. J Virol 2010, 84:5404-5414.

126. Blackham S, Baillie A, Al-Hababi F, Remlinger K, You S, Hamatake R, McGarvey MJ: Gene expression profiling indicates the roles of host oxidative stress, apoptosis, lipid metabolism, and intracellular transport genes in the replication of hepatitis C virus. J Virol 2010, 84:5404-5414.

127. Blackham S, Baillie A, Al-Hababi F, Remlinger K, You S, Hamatake R, McGarvey MJ: Gene expression profiling indicates the roles of host oxidative stress, apoptosis, lipid metabolism, and intracellular transport genes in the replication of hepatitis C virus. J Virol 2010, 84:5404-5414.

128. De Giorgi V, Monaco A, Worchech A, Tornesello M, Izzo F, Buonaguro L, Marincola FM, Wang E, Buonaguro FM: Gene profiling, biomarkers and pathways characterizing HCV-related hepatocellular carcinoma. J Trans/ Med 2009, 7:85

129. Blackham S, Baillie A, Al-Hababi F, Remlinger K, You S, Hamatake R, McGarvey MJ: Gene expression profiling indicates the roles of host oxidative stress, apoptosis, lipid metabolism, and intracellular transport genes in the replication of hepatitis C virus. J Virol 2010, 84:5404-5414.

130. Ouchi M, Ouchi T: Role of IFI16 in DNA damage and checkpoint. Front Biosci 2008, 13:236-239.

131. Kwak JC, Ongusaha PP, Ouchi T, Lee SW: IFI16 as a negative regulator in the regulation of p53 and p21(Waf1).J Biol Chem 2003, 278:40899-40904

132. Rosebeck S, Leaman DW: Mitochondrial localization and pro-apoptotic effects of the interferon-inducible protein ISG12a. Apoptosis 2008, 13: 562-572.

133. Andersen JB, Strandbygard DJ, Hartmann R, Justesen J: Interaction between the 2/-5/ oligoadenylate synthetase-like protein p59 OASL and the transcriptional repressor methyl CpG-binding protein 1. Eur J Biochem 2004, 271:628-636.

134. Scholz C, Tampe R: The intracellular antigen transport machinery TAP in adaptive immunity and virus escape mechanisms. J Bioenerg Biomembr 2005, 37:509-515.

135. Herzer K, Falk CS, Encke J, Eichhorst ST, Ulsenheimer A, Seliger B, Krammer $\mathrm{PH}$ : Upregulation of major histocompatibility complex class I on liver cells by hepatitis $C$ virus core protein via $\mathrm{p} 53$ and TAP1 impairs natural killer cell cytotoxicity. J Virol 2003, 77:8299-8309.

136. Chen L, Borozan I, Sun J, Guindi M, Fischer S, Feld J, Anand N, Heathcote J, Edwards AM, McGilvray ID: Cell-type specific gene expression signature in liver underlies response to interferon therapy in chronic hepatitis $C$ infection. Gastroenterology 2010, 138:1123-1133.

137. Chen L, Borozan I, Feld J, Sun J, Tannis LL, Coltescu C, Heathcote J, Edwards AM, McGilvray ID: Hepatic gene expression discriminates responders and nonresponders in treatment of chronic hepatitis $C$ viral infection. Gastroenterology 2005, 128:1437-1444

138. Khalid SS, Hamid S, Siddiqui AA, Qureshi A, Qureshi N: Gene profiling of early and advanced liver disease in chronic hepatitis $C$ patients. Hepatol Int 2011.

139. Blackham S, Baillie A, Al-Hababi F, Remlinger K, You S, Hamatake R, McGarvey MJ: Gene expression profiling indicates the roles of host oxidative stress, apoptosis, lipid metabolism, and intracellular transport genes in the replication of hepatitis C virus. J Virol 2010, 84:5404-5414.

doi:10.1186/1750-9378-7-7

Cite this article as: Buonaguro et al.: Innate immunity and hepatitis $C$ virus infection: a microarray's view. Infectious Agents and Cancer 2012 7:7

\section{Submit your next manuscript to BioMed Central and take full advantage of:}

- Convenient online submission

- Thorough peer review

- No space constraints or color figure charges

- Immediate publication on acceptance

- Inclusion in PubMed, CAS, Scopus and Google Scholar

- Research which is freely available for redistribution 